\title{
Women in health: Social practices in online health information management
}

\section{Perempuan dalam kesehatan: Praktik sosial pada manajemen informasi kesehatan daring}

\author{
Rizghina Ikhwan \\ Department of Sociology, Faculty of Social and Political Science, Universitas Airlangga \\ Address: Jalan Dharmawangsa Dalam, Airlangga, Surabaya, East Java, Indonesia 60286 \\ E-mail: Rizghina.ikhwan-2014@fisip.unair.ac.id
}

Article History: Received 7 November 2019; Accepted 11 October 2020; Published Online 3 November 2020

\begin{abstract}
Women have the right to take health measures on their bodies. In carrying out health measures, individuals need to seek health information. Health information can be obtained from the environment such as family, neighborhood, and groups involved in it. Along with the increase in technology, information is obtained from the individual environment and the outside world through electronic media and information spread in electronic media can be accessed anytime and anywhere. One of the groups seeking information about health from electronic media is PKK Gunung Anyar Tambak. This study used a qualitative method by conducting in-depth interviews with 16 members of the PKK Gunung Anyar Tambak using snowball sampling. This study found that the information conveyed by women was considered correct after carrying out the information management process with other people, so it requires a negotiation process when taking health measures for their families. In this case, negotiations were carried out with each of the husbands of PKK Gunung Anyar Tambak members. The husband has the power to reject or accept the information conveyed by the wife. The wife must manage online health information obtained from electronic media before it is conveyed to her husband and it can be accepted and practiced in her family.
\end{abstract}

Keywords: women; online health information; social practice; family; information management

\begin{abstract}
Abstrak
Perempuan memiliki hak untuk melakukan tindakan kesehatan atas tubuhnya. Dalam melakukan tindakan kesehatan, individu perlu mencari informasi kesehatan. Informasi kesehatan dapat diperoleh dari lingkungan seperti keluarga, lingkungan tempat tinggal, dan kelompok yang terlibat di dalamnya. Seiring dengan meningkatnya teknologi, informasi diperoleh dari lingkungan individu dan dunia luar melalui media elektronik dan informasi yang tersebar di media elektronik dapat diakses kapanpun dan dimanapun. Salah satu kelompok yang mencari informasi tentang kesehatan dari media elektronik adalah PKK Gunung Anyar Tambak. Studi ini menggunakan metode kualitatif dengan melakukan wawancara mendalam terhadap 16 anggota PKK Gunung Anyar Tambak secara snowball. Penelitian ini menemukan bahwa informasi yang disampaikan oleh perempuan dianggap benar setelah melakukan proses manajemen informasi dengan orang lain, sehingga memerlukan proses negosiasi saat melakukan tindakan kesehatan bagi keluarganya. Dalam hal ini, negosiasi dilakukan dengan masing-masing suami dari anggota PKK Gunung Anyar Tambak. Suami memiliki kekuatan untuk menolak atau menerima informasi yang disampaikan oleh istri. Istri harus mengelola informasi kesehatan online yang diperoleh dari media elektronik sebelum disampaikan kepada suami dan dapat diterima dan dipraktikkan dalam keluarganya.
\end{abstract}

Kata kunci: wanita; informasi kesehatan daring; praktek sosial; keluarga; manajemen informasi

\section{Introduction}

The development of information technology has shifted the source of health information to individuals - sources of health information obtained from the environment, family, doctors, internet, or social media. One of the reasons leading to the formation of patient networks on the internet is that these groups bring alternative perspectives to compare their treatments with others (Lee 2005). Other reasons are the time constraints imposed on medical consultations have led to corresponding increases in online health information searching. Patients have a greater sense of responsibility toward managing personal health (Conrad 2007). The need for information is driven by a problematic situation when one feels able to get input from outside sources (Wersig 2003). In a 
community, life will always undergo socialization and interaction with the environment, making it possible to exchange information. The field of 'consumer health information' has become so crucial that one expert in this field has argued we are witnessing a new information specialism (Gann 1991).

Women who have no experience of pregnancy and a minimum knowledge of baby care will seek new information. It is known as the anomalous state of knowledge in which a person feels that the knowledge level of the information has not enabled them to deal with certain conditions (Belkin 2005). Women are a group of people who have more significant health information needs as they play an essential role in providing for their family's needs and their own; unlike the men who have the task of making a living to fulfill the family unit's needs, women tasks to cultivate the family's needs so that the family can be fulfilled in terms of life necessities. In this case, this refers to the family's health needs, such as reproductive health, nutritious food, and keeping the home hygienic. With the advancement in the information available, women can access the sources of information through electronic media (internet), social media (Instagram, Facebook, Twitter), and health applications (Halodoc, Samsung Health I-care, Google Fit). The internet can provide resources and information to bolster patients' abilities to question their physician's opinion, seek alternative treatment options, and access second opinions (Gage \& Panagakis 2012); therefore, women have the right to obtain health information. The dominant discourse here says one of the rights, where the right to information and the right to information is in the individual, not a chance to do so (Gann \& Needham 1992). The new information obtained through electronic media allows for differences compared to the information obtained from the family environment that tends to be traditional or cultural.

Concerning gender studies, women's position as part of the family affects their actions when practicing the electronic media's health information. These are evidence of patient self-advocacy, facilitated by internet technology, to facilitate more informative, inclusive, and proactive participation in health care interactions (Rogers 2004). Women do not immediately determine the choice of health practice for themselves or their family members because women are under the power of their husbands as to the head of the family. The position of women is subordinate in the family environment. On the other hand, women who seek out health information using electronic media convey it to their fellow women in this way because it feels more acceptable (Bell 2014). The relationships within the female interactions consider being more open and free. Parry (1979) stated that the study of caste and kinship in Kangra frequently mentions joint family interests do not coincide with individual sons and their conjugal families' interests for contributions to, reliance upon, and consumption of joint family resources are generally unequal.

These women have formed a group informally in Surabaya Citu, namely PKK Gunung Anyar Tambak.Family Welfare Development or Pembinaan Kesejahteraan Keluarga, after this referred to as PKK, is different from the PKK group for the association of housewives in the middle and upper residential areas with an excellent socio-economic background. This background supports the mothers in PKK Gunung Anyar Tambak when they are receiving new information. It is evidenced by PKK Gunung Anyar Tambak, which is not filled with public events such as save the loan. In every meeting held once a month, they discuss various current topics as part of a sharing session. This activity shows that women in PKK Gunung Anyar can convey and express their opinions and accept other group members. The sharing session discusses women's and women's health (reproductive health, maternity health, and toddler health). There are also activities like "Myth or Fact" where the mothers of the group analyze and determine whether the community's issues are false or reliable news. In the context of gender analysis, the activities undertaken by the members prove that women have the right to convey their opinions or knowledge when it comes to the health information obtained and delivered on electronic media.

Brubaker (2007) discussed health information concerning gender; The United States saw that the interactions between the different gender attitudes in the family structure indicate higher behavior associations. Regarding responsibility when oriented to non-traditional matters (Brubaker 2007), individuals orientate based on gender about their health behavior. The study found that women are more responsible for their health as they perform various actions to prevent or treat associated 
problems. In addition, women are not only responsible for themselves but also for the health of their families. Foster (2017) revealed that the internet's social connectivity affects the exchange of knowledge among the sick, which causes the dilemma that people who are sick in online communities assess each other as sources of information about their health. According to Brubaker (2007) and Foster (2017), there was a gap concerning gender and health issues with the information sourced from electronic media. This research has thus raised the topic of gender relations within the health behaviors in PKK Gunung Anyar Tambak. As a group of women who routinely discuss health using information sources from the Internet, the women's actions in PKK Gunung Anyar Tambak are related to their family environment. This research focuses on how social practices are engaged in the process of information absorption. Online health information search is a way of negotiating in channeling new health information in his family.

\section{Research Method}

The type of research used was qualitative, the descriptive data based on the interactions' results, and the subject's observations. This study describes the actions of women exchanging health information when obtaining them from electronic media. It is to manage the information and practice health advice on their family. Judging from the mother's actions of the group members PKK Gunung Anyar Tambak, absorbing health information from electronic media then allows for managing information within the group. It makes them ready to negotiate new health information for her family. In terms of tracing and revealing the reality, qualitative research methods can help the researchers describe and present a detailed overview of the comprehensive data or the state of the subject and the research objects used to discover and understand the reality. Those, as mentioned earlier, hid behind phenomena that are sometimes difficult to understand. Using qualitative methods to examine these phenomena can make it possible to explain in more detail and depth.

According to the reality of women's position in the family, women were made the subject of this research by considering each individual's subjective meanings. The subjective meanings that exist in the individual have different backgrounds that can reveal the position of women in the health areas reviewed through the process of searching for and managing health information by analyzing the data according to the social practices of Pierre Bourdieu. It can be traced to the reality of women's social practices in health information management and the women's negotiation process as part of the family. This research conduct on the mothers in PKK Gunung Anyar Tambak, who seek and obtain health information from electronic media (internet), social media (Instagram, Facebook, and Twitter), and health applications (Halodoc, Samsung Health, I-care, Google Fit). As a group or association of women in Gunung Anyar Tambak Village that regularly holds meetings, various activities are conducted, such as borrowing and sharing sessions. In these sessions, a variety of discussion topics are engaged. Each meeting raises various issues such as reproductive health, environmental health, pregnant women's health, and toddlers' health. As a group of women living in large cities such as Surabaya, the mothers in PKK Gunung Anyar Tambak is the most dominant community of people accessing information in the electronic world and being among those actively using social media. In addition, the neighborhood housing in Wiguna (Wisma Gunung Anyar) provides various facilities that support the absorption of health information.

The PKK Gunung Anyar Tambak group has 46 members who actively follow the regular meetings every day of the week at the beginning of the month. These women have various backgrounds (housewives, officers, and entrepreneurs). In every meeting, there is 150.000 IDR to be used as a speaker fee and support operations. In addition to routines, the group also conducts social activities in plastic waste management, integrated healthcare center or pos pelayanan terpadu (posyandu) tourism, orphanage group visits, and tourist attractions. Doing this routine once a year, this study's subjects were members of the PKK Gunung Anyar Tambak, categorized according to informant criteria. The critical informant was Mrs. IV, the chairwoman of PKK Gunung Anyar Tambak. Mrs. IV was chosen based on the rugged membership structure. They also have the most in-depth information about PKK Gunung Anyar Tambak's activities. The subject informants were 16 active members determined using the snowball technique. Mrs. IV directed the researchers to its members; 
the non-subject informants totaled as many as three people, including Mr. E, the husband of Mrs. IV, Mr. Y, the husband of Mrs. A, and Mr. KT, the husband of Mrs. FT. The non-informants were used by the researchers to examine the other angles in the family. This way, the researchers observed the relationship between the husband and wife in maintaining the family's health.

The data collection involved both primary and secondary data. The primary data was obtained through two deep interview stages, questions, and answers directly using the interview guidelines directed and focused - interviews conducted with open questions for PKK Gunung Anyar Tambak in answering questions. The second stage was the observation stage; in this stage, the researchers observed PKK Gunung Anyar Tambak in the event sharing sessions to learn about the actions and behavior of the members when discussing, conveying, and processing the information obtained from electronic media, mainly the information focused on health issues. The field's data supported by the secondary data obtained from the literature, including books, journals, articles, and numerical data. It was in addition to the demographic data from the Gunung Anyar Tambak Village. Data analysis techniques used to explore the meanings and expressions implied from interviews and observations. The interviews with the informants were the form of transcripts that then grouped according to the research questions. The questions were established based on the social practices in the absorption of online health information conducted by the group members. The process of negotiation is conducted by the members when conveying new health information in the family. The grouped data has then been presented in narrative text form based on the set of structured information in order to conclude. Searching for the meanings in PKK Gunung Anyar Tambak's activity was done by observing each symptom. It was to note the pattern of any explanations and configurations that may exist and the causality and proposition flow. Each conclusion will continue to be verified until it is entirely valid and sturdy to answer the research question.

\section{Results and Discussion}

\section{Gender in health}

Brubaker (2007) examined gender views in order to explore the differences in health behavior. Using social construction analysis, the study argues that health behavior is also gender-related because of the combination of individual institutions, structural opportunities, and whatever constraints are involved, meaning that individuals construct gender in multiple ways. One of them is analyzing two individual-level indicators, precisely gender attitude and personality traits based on gender. Individuals use gender to guide their social interactions in institutions such as when at work and among the family. There is also an intersection between the individual level and the gender indicators in institutional-influenced health behavior. This research's health behaviors include selfhealth screening and medical check-ups, and behavioral risk includes risky sexual behaviors and drug abuse (Brubaker 2007). The findings show that gender is associated with risky behavior rather than health behaviors, especially among women. In addition, gender views are more associated with individual gender actions. It is not only concerning the health-related relationships within the family and broader employment. It is in addition to the genders' personality traits and the strength of the associated behavior, which is often relatively healthy.

Alfani (2009) argues that to meet every health information need, the experience influences health information sources. In addition, there are differences in the search behavior for health information between men and women, especially in terms of the type of health information sought. Among the PKK Gunung Anyar members, it found that women emphasize the attention paid to family health and caring for their child's nutrition. The subject seeks additional health information from the internet to minimize the lack of information and collaborate with the various health information. According to Seckin (2010), the importance of patients acting as information managers encourages individuals to build their adaptations and skills concerning self-care by collecting information from various digital sources. The sources of information obtained from the surrounding environment tend to be hereditary traditions or cultures. In fulfilling the knowledge and insight as new parents, pregnant women and 
toddlers get it in various ways, namely by reading books while pregnant, asking their parents or relatives, consulting with medical personnel such as doctors, midwives, and other health practitioners, asking friends those with more experience or looking for information from the internet (DeHoff et al. 2016).

Notoatmodjo (2003) said that before the individual adopts a new behavior, in the individual itself, there is a sequential process that involves the following: 1) awareness (consciousness) where the person realizes, using the sense of knowing, what the stimulus (object) is first, 2) interest, people are interested in the stimulus, 3) evaluation (they cogitate good and whether the stimulus is for them), 4) trial, where people start to try the behavior, and 5) adoption, where the subject behaves in a new manner according to their knowledge, consciousness, and attitude towards the stimulus. The need for information occurs when circumstances arise due to a gap between the human being and the knowledge that they need. Individuals will seek out information to fulfill their needs because of their knowledge gaps. These individuals will then use or strive to use various sources of information (Pannen 1990). Human beings have an internalized scheme in their lives. Through these schemes, they are disregard, understand, appreciate, and evaluate their social reality. The scheme forms a cognitive structure that provides a framework of reference for individuals' actions within their daily lives (Suyanto 2010). Bourdieu uses the agency to refer to an agent, such as the individual who is the social subject. Agency, in Bourdieu's perspective, is the idea that every individual has been equipped with the ability to understand and control their actions based on the conditions in which the individual resides. It is often associated with intentionality and individuality (Webb et al. 2002).

Foster (2017) reveals that the internet's social connectivity affects the exchange of knowledge among sick people. The exchange of knowledge leads to the dilemma of sick people in online communities, and they assess each other as a source of information about their health. The background of this research problem is the increasing number of patients seeking medical information on the internet. Therefore, it is necessary to understand the impact of this action on their health, the role of patientpractitioners, and the provision of general health care. The data was collected by conducting semistructured interviews with the patients seeking online health information before or after a formal medical consultation (Zufferey et al. 2010). The researchers described the search motive for online health information in the context of the physician-patient relationship in Switzerland in terms of symbolic interactionism. A grounded theory approach allowed the study to get an overview of the information search motives concerning health in the context of the physician-patient relationship in Switzerland. This approach is suitable for the development of an inductive theoretical model for problematic behavior. The findings related to patients seeking medical information online are because they use it to prepare for the consultation, complete it, validating it, and/or challenging the results.

The initial motivation for finding online health information is identified by the need for recognition, the reduction of uncertainty, and perspective. What drives the search for health information online are personal and contextual factors, namely, a sense of self-responsibility and the opportunity to use the internet. Online health information searches are less concerned with what happens during a consultation than before or after a sociocultural context. Like the group PKK Gunung Anyar whose members seek online health information to meet their family's needs, they have a sense of responsibility due to their position as women providing health care for their family members. Health behavior is one of every family's basic needs; Kivits (2009) explores the relationship between Internet use and individual health experiences.

Adopting a mediated health approach, the study presents four household case studies with internet access to access health information. The informants use the internet because it offers personalized information according to the individuals and their families' health needs, affecting their daily routine. The internet appears to be a daily chore associated with the intimacy of the health experience. Private Internet use faces environmental information, generating information flows that can cause uncertainty on the information seeker's side. Personal health experiences and online media usage affects online health information retrieval in the context of everyday Internet use (Kivits 2009). Social networking improves the community's health behavior by providing social support and information to improve public health (Zhao \& Hu 2016). 
Field (2003) mentions that communities with strong social networks have a death rate that is a third of the community's death rate whose social bonds are weak. The internet itself forms the basis of and symbolizes the information era. More than any other technological form, it allows people to access broader health information and medical coverage. In this discussion, the importance of internet use and health information practices has been examined concerning daily health and the context of health information. This research focuses on using the internet concerning health in offline search information through the analysis of the social construction theory by Peter L Berger. The interactions between health and the media are where the information is conveyed through different media channels addressing individual health experience. Understanding the individual use of the media can have an impact on the individual health experience. In turn, the health experience integrates the media's use and considers the relationship between individuals and information. Based on this practice, it is necessary to consider the more comprehensive information environment and its relationship to individuals' daily health experiences and their personal use of media and online health information. It is essential to examine the online space dedicated to health information and information search practices to understand better internet use contributions to building understanding and health knowledge.

Discussing based on literature; gender relations with health behavior, online health information exchange, and online health information searches have been analyzed according to social constructs and actions related to health behavior in everyday life. It later found no discussion of the woman judging by the actions in exchange for health information obtained from electronic media to be managed and practiced on her family.

Bourdieu gained awareness about the importance of domination and symbolic systems in social life and the idea of social order that would eventually be transformed into select theories (Web et al. 2002). Bourdieu's thinking is that the focus of society is being formed through its objective and subjective structures. He saw that the subject and the outside world were also agencies and structures, not two separate things. It means that the outside world's subjects and the structures and agencies therein are not something that can be radically divided. More than that, these two aspects are interconnected within complex processes that generate social practices within the community. Bourdieu sees the actor as having a habitus that features a cognitive structure used to understand the social world (Harker et al. 1990). The collective knowledge of reality forms PKK Gunung Anyar Tambak's actions. The cognitive structure that has emerged from the habitus owned by PKK Gunung Anyar Tambak shows a pattern when understanding the social world.

Kleden (2005) outlines the seven primary elements of this habitus: 1) product history is a long-lasting disposition device gained through repeated exercise (inculcation), 2) they are born in a particular social condition and therefore become part of a structure that has been given shape in advance by the social condition in which they are an in-product. In other words, it is a structured structure, 3) this structured disposition also serves as a framework that forms the perception, representation, and actions of a person, therefore becoming a structure in itself, 4) Habitus is created under certain social conditions. This habitus can be transferred to other social conditions and is therefore transposable, 5) pre-consciousness does not constitute the results of a reflection or a rational consideration; it is more of an unknowing and undesirable spontaneity; however, it is also not a mechanistic movement without any historical background, 6) It is orderly and patterned but not in submission to specific rules. Habitus is not only a state of mind; it is also a state of the body and even a site of incorporated history, and 7) habitus may be directed toward the purpose and outcome of a particular action without the intention to achieve such results consciously and without the mastery of a specific intelligence with which to achieve it (Duplaga 2015).

\section{Online health information management}

Bourdieu's field concepts have been used as a reference framework for understanding the environmental structures that prepare and guide the strategies used by the occupants of a particular position (individually and collectively) trying to protect or improve their position (Ritzer \& Goodman 2003). 
These impose the most profitable social level principles on their products (Ritzer \& Goodman 2004). Therefore, in this research, health information negotiations are an awareness-based struggle that the group members own while the family environment is close to the surrounding culture. Resources as a particular social capital are owned by young mothers to fight for access to health information that is more appropriate to the family environment. It produces the practice of the negotiation of health information. On the one hand, we might term the critique of information which, rather like the celebratory approach discussed above, highlights the diversity, complexity, and sheer proliferation of information sources. For Lash (2002), discursive knowledge has been displaced by what he calls informational knowledge. While discursive knowledge implies a unity, a set of beliefs, values, and disciplinary underpinnings, informational knowledge, by contrast, has no unity- it is characterized by disembeddedness, spatial compression, temporal compression, real-time relations (Lash 2002).

Common sense is the knowledge that individuals share with other individuals in their daily lives (Berger \& Luckmann 1990). Knowing this is by looking at the extent to which members obtain new health information if the family environment depends on the absorption of mothers of the PKK Gunung Anyar Tambak group regarding health information obtained from social media. Determines how to maintain this habit in the family environment based on the members' social capital, which Bourdieu calls capital. Bourdieu states a generative formula used for describing social practices: (habitus x modal) + realm $=$ practice $($ Harker et al. 1990). Bourdieu's thoughts on social practices, in this study is an overview of group members' activities in negotiating health information. Habitus members in PKK Gunung Anyar Tambak have an awareness structure used to negotiate health information in the family environment using social capital from accurate knowledge obtained from social media, and it has been discussed in groups. The negotiation of the group members' health information is a form of struggle to make adjustments to get a family position. It means that they strive to convey new information acceptable to their family (Guffey 2017).

\section{Social practices in online health information management}

Women of high and low socioeconomic status (SES) learned about health, in this case, their reproductive health, in very different ways. Understanding why there are differences in health communication between social classes is essential because it has significant implications for health care and its outcomes (Brodie et al. 2000, Kontos et al. 2007, Viswanath 2008). The practice of negotiation occurs in the realm that regulates the position of individuals in the social space. In this case, the family environment's position in the family environment is where the husband has the highest position. The family is a social space in which some domains govern the positions of the family members. As individuals, the family members are inferior to the husband's position, which is more robust and powerful. The members of PKK Gunung Anyar Tambak are part of the habitus connecting the family members and the various social realities that produce actions according to the realm and capital therein. In this case, the members, as social users, gain access to a new health information source. The negotiation practice is done by the PKK Gunung Anyar Tambak mothers to convey and apply the health information obtained from social media, so all family members accept it.

The woman's actions in terms of the health practices are a right that is in her possession. When conducting actions concerning health, the individual will have previously sought health information. The way to obtain health information is through the environment, such as family, area of residence, and groups. Along with the increase in technology use, the information obtained from a unique environment; however, it can also form the outside world through electronic media. The information scattered across electronic media can be accessed at any time and anywhere. PKK Gunung Anyar Tambak consists of women looking for health information on electronic media using various sources. It can include the use of applications on smartphones and social media. Members process new health information obtained before practicing it in everyday life. Among the group's routine activities, one is a 'sharing session' held to share information and discuss various exciting things. In each meeting, the themes will be determined, ready to be discussed in the next meeting. According to PKK Gunung Anyar Tambak, Mrs. IV, this event is very beneficial for the members. In addition, the discussion becomes more directional. 
The theme of this event is often the "hot news" in the community. It also raises common themes, such as business, beauty, and health. According to G, as a physician in the PKK Gunung Anyar, she often faced questions from the other members about health. It makes the sharing session lead to health issues. The PKK Gunung Anyar will share the information they have obtained from electronic media to discuss it together. According to the RH doctors, not all of the information obtained from electronic media is correct. They, therefore, need to consider the source of information. From the discussions conducted with the PKK Gunung Anyar Tambak, the members feel that the information obtained from the electronic media sources is more accurate because it has been through the discrediting or crediting process. Health information on social media is not accepted in raw form; however, it has been through management through the discussion itself. The health information conveyed to each member of the group's family is seen to be more acceptable.

Women, as a group of people, are considered weak. They often face injustice even within their family. Medical knowledge-seeking among laypeople could originate from an experience of powerlessness and could be a strategy patients use to regain control over their situation (Asbring \& Närvänen 2004). One of these forms of injustice is distrust when they are conveying the information that they possess. In the family environment, men as their husbands have supreme power, and the husband determines what will be done in and by the family. According to Mr. X, who has a business in the furniture sector, when his wife gets information from the internet, this should not be practiced because it is considered inaccurate. The women are indirectly discriminated against in terms of the delivery of the information that they acquire. The information deems correct after an information management process is conducted. It requires a process of negotiation when conducting health measures for the family. In this case, the negotiations are conducted with the husband. The husband has the power to refuse or receive the information conveyed by his wife. The wife must manage the online health information obtained from the electronic media before delivering it to her husband for them to ensure that it is acceptable.

\section{Conclusion}

The actions undertaken by the PKK Gunung Anyar Tambak are a social practice that done when individuals need new information to fulfill their needs. New information is obtained from electronic media because it is considered more accessible and more practical. The information provided in electronic media forms the individual's habitus as a consumer of electronics. The health information was obtained from the group members' electronic media and processed through discussions to obtain more accurate information. It has been done so then the online health information is accepted by the family, especially the group members' husbands, who can determine the family's actions.

The social practice conducted by PKK Gunung Anyar Tambak is searching for health information online using electronic media. The new online health information must go through the dominant and symbolic system in the family's social life where the husband is the household head. As a structural awareness process for the women who belong to the PKK Gunung Anyar Tambak, the discussion activities focused on the new health information obtained from social media are used to negotiate the family environment. Health information negotiations see as a struggle for consciousness conducted by the women in PKK Gunung Anyar Tambak. In the family, it is done by looking at how the members maintain the information. New health information is gained when the family environment depends on the maternal absorption of the reality or truth of the health information obtained following the discussion. The family becomes a social space where there are various rules. The negotiation practice is done by the PKK Gunung Anyar Tambak group members to convey and apply the health information obtained from social media to accept in the family environment.

\section{References}

Alfani R (2009) Perilaku pencarian informasi kesehatan studi deskriptif tentang perilaku pencarian informasi kesehatan di Kota Surabaya. Doctoral Dissertation, Universitas Airlangga, Surabaya. 
Asbring P \& Närvänen A (2004) Patient power and control: A study of women with uncertain illness trajectories. Qualitative Health Research 14 (2):226-240. https://doi.org/10.1177/10497 32303260682.

Bell AV (2014) "I think about Oprah": Social class differences in sources of health information. Qualitative Health Research 24(4):506-516.https://doi.org/10.1177\%2F1049732314524637.

Belkin NJ (2005) Anomalous State of Knowledge. New Jersey: American Society of Information Science and Technology.

Berger LP \& Luckmann T (1990) Tafsir Social Atas Kenyataan: Sebuah Risalah tentang Sosiologi Pengetahuan. Jakarta: LP3ES.

Brodie M, Fournoy RE, Altman DE, Blendon RJ, Benson JM, \& Rosenbaum MD (2000) Health information, the internet, and the digital divide. Health Affairs 19 (6):255-265. https://doi. org/10.1377/hlthaff.19.6.255.

Brubaker CE (2007) Doing health, doing gender: Testing a social constructionist view of health and risk behavior engagement. Dissertation, University of Massachusetts, Amherst.

Conrad P (2007) Medicalization of society. Baltimore: The John Hopkins University Press.

DeHoff BA, Staten LK, Rodgers RC, \& Denne SC (2016) The role of online social support in supporting and educating parents of young children with special health care needs in the United States: A scoping review. Journal of Medical Internet Research 18 (12):e333. https:// doi.org/10.2196/jmir.6722.

Duplaga M (2015) A cross-sectional study assessing determinants of the attitude to the introduction of ehealth services among patients suffering from chronic conditions. BMC Medical Informatics and Decision Making 15 (33). https://doi.org/10.1186/s12911-015-0157-3.

Field J (2003) Modal Sosial. Bantul: Kreasi Wacana.

Foster DM (2017) Being sick online: Exchanges of medical knowledge on the internet. Dissertation, The University of Michigan, Michigan.

Gage EA \& Panagakis C (2012) The devil you know: Parents seeking information online for paediatric cancer. Sociology of Health \& Illness 34 (3):444-458. https://doi.org/10.1111/ j.1467-9566.2011.01386.x.

Gann R (1991) Consumer health information: The growth of an information specialism. Journal of Documentation 47 (3):284-308. https://doi.org/10.1108/eb026882.

Gann R \& Needham G (1992) Promoting choice: Consumer Health Information in the 1990s. London: Consumer Health Information Consortium.

Guffey T (2017) Smartphone application self-tracking use and health. Dissertation, The Texas Woman's University, Denton.

Harker R, Mahar C, \& Wilkes C (1990) (Habitus X Modal ) + Ranah = Praktik, Pengantar Paling Komprehensif Kepada Pemikiran Bourdieu. Yogyakarta: Jalasutra.

Kivits J (2009) Everyday health and the internet: A mediated health perspective on health information seeking. Sociology of Health \& Illness 31 (5):673-687. https://doi.org/10.1111/j.14679566.2008.01153.x.

Kleden I (2005) Habitus: Iman dalam Perspektif Cultural Production. RPA Sunarko et al. (eds). Bangkit dan Bergeraklah: Dokumentasi Hasil Sidang Agung Gereja Katolik Indonesia. Jakarta: Sekretariat SAGKI.

Kontos EZ, Bennett GG, \& Viswanath K (2007) Barriers and facilitators to home computer and internet use among urban novice computer users of low socioeconomic position. Journal of Medical Internet Research 9 (4):e31. https://doi.org/10.2196/jmir.9.4.e31.

Lash S (2002) Critique of Information. London: Sage.

Lee H (2005) Implosion, virtuality, and interaction in an internet discussion group. Information Community Social 8 (2005):47-63. 
Notoatmodjo S (2003) Pengembangan Sumber Daya Manusia. Jakarta: PT. Rineka Cipta.

Pannen P(1990)A study in information seeking and use behaviors of resident students and non resident students in Indonesian tertiary education. Dissertation, Syracuse University, New York.

Parry J (1979) Caste and kinship in Kangra. London: Routledge \& Kegan Paul.

Ritzer G \& Goodman DJ (2004) Teori Sosiologi: Dari Teori Sosiologi Klasik Sampai Perkembangan Mutakhir Teori Sosial Postmodern, Terjemahan Nurhadi. Yogyakarta: Kreasi Wacana.

Rogers A \& Mead N (2004) More than technology and access: Primary care patients' views on the use and non-use of health information in the internet age. Health Social Care Community 12 (2):102-10. https://doi.org/ 10.1111/j.0966-0410.2004.00473.x.

Seckin G (2010) Patients as information managers: The internet for successful self-health care \& illness management. Open Longevity Science (4):36-42. http://doi.org/10.2174/187632 6X01004010036.

Suyanto B (2010) Anatomi dan Perkembangan Teori Sosial. Yogyakarta: Aditya Media Publishing.

Viswanath K (2008) Social Capital and Health Communications. In: Kawachi I, Subramanian SV, \& Kim D (eds). Social Capital and Health. New York: Springer.

Webb J, Schirato T, \& Danaher G (2002) Understanding Bourdieu. London: SAGE Publication.

Wersig G (2003) Information Theory. London: International Encyclopedia of Library and Information Science.

Zhao Y \& Hu Q (2016) Impact of social networks on healthy behaviors: An example of breastfeeding in western China. China Journal of Sociology 2 (1):129-143. https://doi. org/10.1177\%2F2057150X15622381.

Zufferey MC, Abraham A, Sommerhalder K, \& Schulz PJ (2010) Online health information seeking in the context of the medical consultation in Switzerland. Qualitative Health Research 20 (8):1050-1061. https://doi.org/10.1177/1049732310368404. 